\title{
新幹線初のフィンバック橋の設計・施工 一北陸新幹線姫川橋りょう一
}

\author{
萩原秀樹*1 ・清田三四郎 ${ }^{* 2} \cdot$ 武田哲郎*3 $・$ 宮前俊之*4
}

1.はじめに

北陸新幹線姫川橋りょうは，新潟県系魚川市に位置し， 一級河川姫川を渡河する $462 \mathrm{~m}$ の橋梁である。本橋梁 は, 新幹線の橋梁形式として初めて採用する $\mathrm{PC}$ フィン バック橋で，橋梁支点部に魚の背びれ（フィンバック） のようなウェブを突出させた中路構造であり，鉄道橋上 しては単線断面の仙石線鳴瀬川橋梁（6 径間連続桁）に 採用されているが，複線断面としては初の採用となる。 また, 本橋梁の施工は, 北陸地域上いう積雪寒冷地, お よび日本海海岸線から約 $700 \mathrm{~m}$ の塩害環境下という, 厳しい条件の下で行っている。

本稿は, 姫川橋りょうの設計と，3期にわたる上部工 の施工のうち，完了した 2 期間の施工についての報告を 行うものである。

\section{2. 工事 概 要}

本橋梁の施工位置図を図-1に, 工事概要を表-1に, 一般図を図-2 に示す。

\section{3.フィンバック橋の特徵}

フィンバック橋の構造的な特徵は，以下のようなこと が挙げられる。

1）橋面上に突出させたウェブ断面で, 中間支点部の 負の曲げモーメントとせん断力に対して抵抗させる こと。

2）支点上部に PC ケーブルを配置することにより偏 心量を大きく取れ，桁高を变えることなく桁下空間 を確保でき，堤防管理用道路の建築限界を確保する とともに線路縦断を低く抑えることが可能なこと。

3）断面に曲線形状を施すことにより, 背景の山並办 に調和すること。

＊1 はぎわら・ひでき/鉄道建設・運輸施設整備支援機構 北陸新幹 線第二建設局 系魚川鉄道建設所 所長

*2 きよた・さんしろう/鉄道建設・運輸施設整備支援機構 北陸新 幹線第二建設局 系魚川鉄道建設所 所員

＊3 たけだ・てつろう/ピーエス三菱・興味・常盤 JV 姫川 B 上部 工作業所 所長 (正会員)

*4 みやまえ・としゆき/㑣ピーエス三菱 東京土木支店 技術部

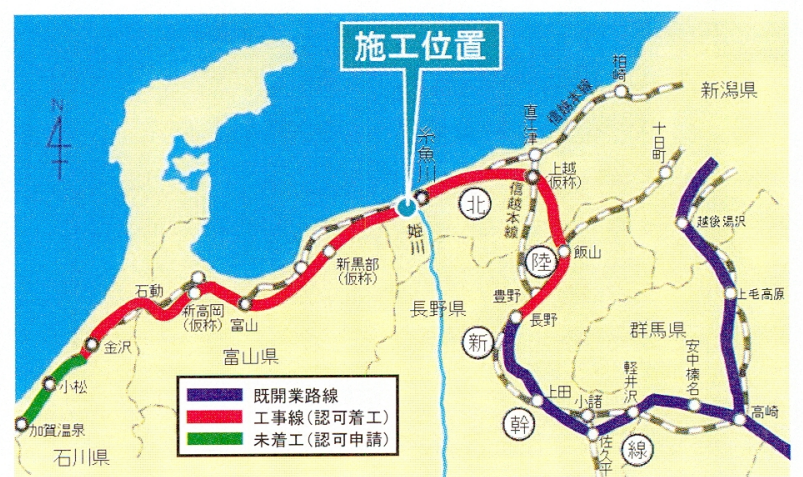

図-1 施工位置図

表-1 工事概要

\begin{tabular}{|c|c|}
\hline 線路規格 & 北陸新幹線 \\
\hline 工. 事. 名 & 北陸幹 (上・糸), 姫川 $\mathrm{B}$ 上部工他 \\
\hline 発 注 者 & $\begin{array}{l}\text { 独鉄道建設・運輸施設整備支援機構 } \\
\text { 鉄道建設本部＼cjkstart北陸新幹線第二建設局 }\end{array}$ \\
\hline 施 工者 & ピーエス三菱・興和・常磐 JV \\
\hline 構造形式 & 7 径間連続 PC フィンバック橋 \\
\hline 橋 & $462.0 \mathrm{~m}$ \\
\hline 支間 & $57.0+69.0+3 @ 70.0+69.0+57.0 \mathrm{~m}$ \\
\hline 列車荷重 & 標準活荷重 P-16 \\
\hline 設計速度 & $260 \mathrm{~km} / \mathrm{h}$ \\
\hline 平面線形 & 直線 \\
\hline 縦断勾配 & $6 \%$ level \\
\hline 施工条件 & 3 期非出水期施工（10 月～5 月） \\
\hline 架設方法 & 固定式支保工架設 \\
\hline
\end{tabular}

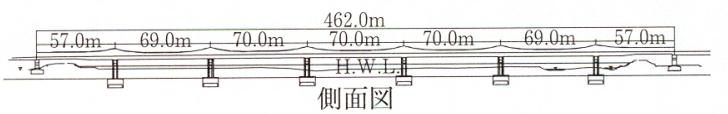
支間中央部 \& 支点部

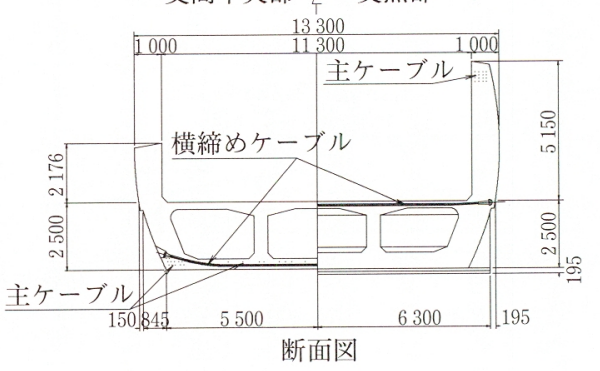

図-2 姫川橋りょう一般図 
4. 設計

\section{1 設計解析}

（1）設計上の留意点

設計上の留意点は以下のとおりである。

1）日本海に面した厳しい塩害環境条件に位置するた め, PC 構造とした。

2）桁形式は中路断面であり，堤防上の管理用通路高 を確保するために，側径間は標準部に対し $1 \mathrm{~m}$ 低 い断面を採用した。

3）側径間のフィン高を隣接する桁式高架橋部の高欄 天端に一致させ連続性を図った。また，フィンの最 大高は, 除雪可能な R.L.+4.5 m を限界高さとした。

4）打継ぎ位置は一般的には完成時に曲げモーメント が交番する $0.2 L$ ( $L=$ 支間長) 付近に設ける場合 が多いが，径間長が長く施工時に既設径間側で正の 曲げモーメントが卓越することから $0.25 L$ 付近と して，発生断面力を小さくした。

5）箱桁部外側ウェブを，景観上から斜めウェブにし 底版幅を狭くしたため，フィン自重および支点上フィ ンに配置した PC ケーブルの腹圧力により, 支点部 上床版には橋軸直角方向に引張力が生じる。このた め，上床版に横締め PC ケーブルを配置して引張力 に抵抗させた。

（2）主方向の解析

1）主方向の解析は，梁理論による平面骨組解析によ り，施工ステップを考慮した断面力を算出した。

2）クリープ・乾燥収縮の影響は，打設部材（区間） の材齢差を考慮した。

3）桁全体を格子構造として解析し，内桁，外桁の断 面力分担，および各支承の反力分担比を算出した。

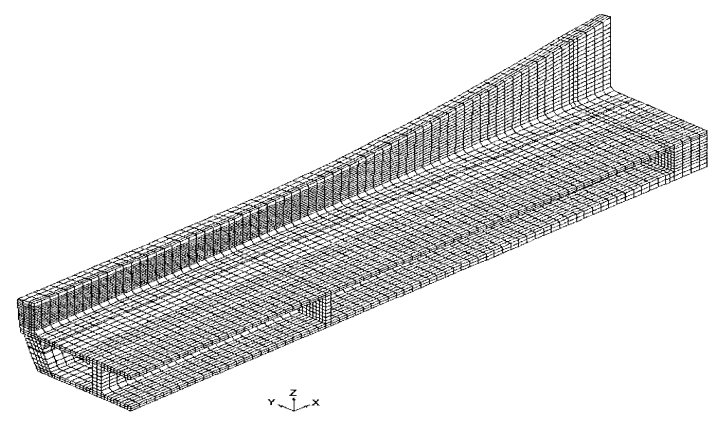

図-3３次元 FEM モデル
（3）横方向の解析

1）設計断面力の算出は，ボックスラーメン骨組解析 により行った。

2）主桁断面寸法が变化しているため，各部材の岡性 に着目して中央径間中央, 中間支点, 側径間中央, 端支点の 4 断面について検討を行った。

3）ボックスラーメン骨組解析の妥当性，および，横 締め PC 鋼材の配置範囲について，3 次元 FEM 解 析により検証した。

\section{2 立体 FEM による構造解析}

本橋梁における構造特性について, 図-3に示す 3 次 元モデルを用いて FEM 解析を実施し, 以下の 2 点につ いて確認した。

（1） PC 鋼材定着位置におけるプレストレスの有効 領域の評価

大断面のため, ウェブ定着 PC 鋼材によるプレストレ ス分布を確認した結果，各部位の応力度分布を指標とし て計算した結果と，鉄道構造物等設計標準（コンクリー ト構造物）に示される式により算出した結果が，おおむ ね同じ結果となったため，後者を用いて設計を行った。

（2）中間支点上の曲げ下げ $\mathrm{PC}$ 鋼材による腹圧力の 影響

前述した，ウェブの自重および $\mathrm{PC}$ 鋼材の腹圧力によ る橋軸直角方向の引張力について, 解析よりこれらの荷 重の影響範囲を求め，図-4に示すような横締め PC 鋼 材の配置とした。

\section{5. 施工計画}

\section{1 施工段階}

姫川は，国土交通省管理の 1 級河川であり，集中豪雨 や台風等洪水が発生しやすい時期を除く非出水期（10 月〜 月 月）の施工に限定された。施工方法は，固定式支 保工による 7 施工区分の分割施工であり，7施工区分を 3 期の非出水期に分けて施工することとした。施工段階 困を図-5に示す。

第 1 非出水期 第 2 非出水期 第 3 非出水期

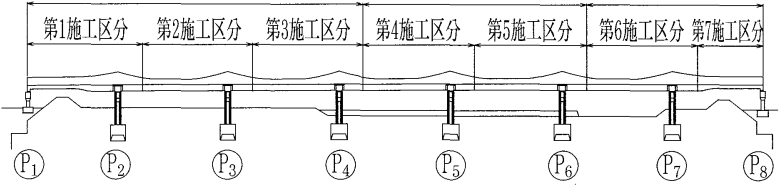

図-5 施工段階図

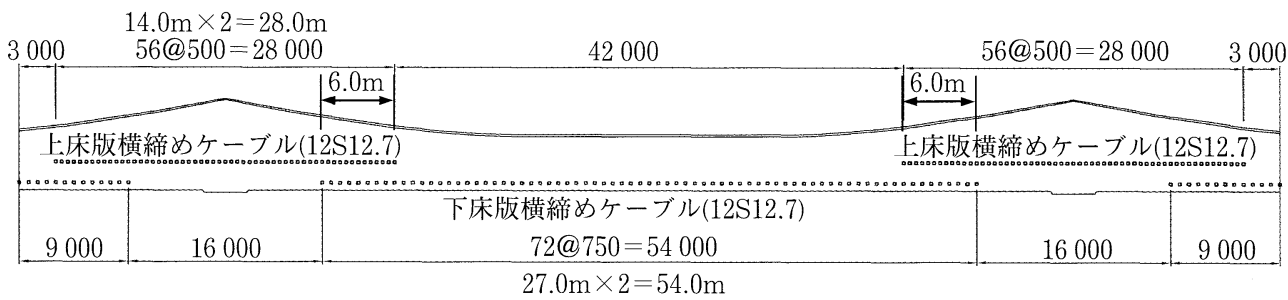

図-4 横締 PC 鋼材の配置図 


\section{2 分割打設の検討}

1 つの施工区分に扮ける主桁のコンクリート打設は, 耐久性から 1 回で行うこ之が好ましいが，打設数量が約 $1500 \mathrm{~m}^{3}$ 之多く，打設に要する時間が長時間之なる，鉄 筋・PC 鋼材の保持が困難である, 型枠支保工の設置が 困難であるという理由から，1施工区分をさらに4ブロッ クに分割して打設することとした。施工性， PC 鋼材の 配置，打設数量等を考慮し決定したブロック分割図を 図-6に示す。分割にあたり，次の検討を行った。

1）打継ぎ部の拘束および温度勾配の影響によるひび 割れ対策の検討。

2）打設から緊張までの期間が長くなる部位に打いて, 乾燥収縮による变形を型枠が拘束することによって 発生するひび割れ刘策の検討。

\section{3 温度解析}

分割打設により生じる打継目には，新設コンクリート の水和熱による温度上,㫒, 外気温の影響, 既設コンクリー トによる拘束によりひび割れが発生する可能性がある。

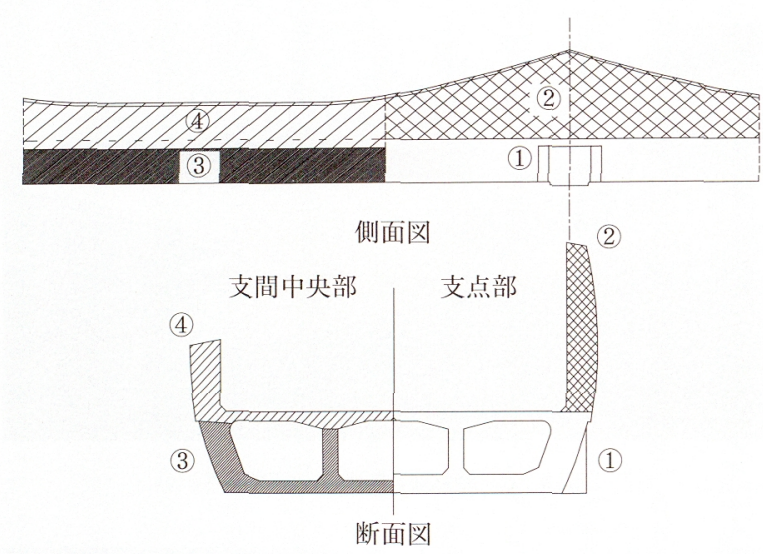

図-6 打設ブロック分割図

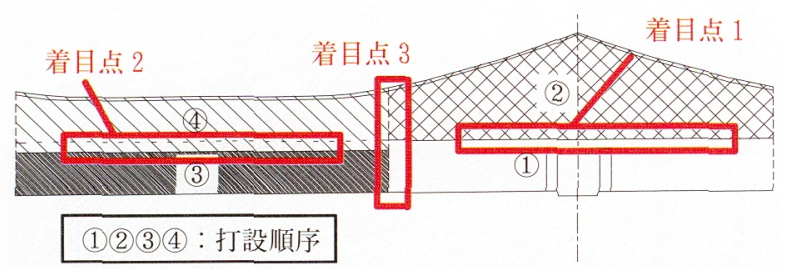

図-7 温度解析検討箇所
そこで，３次元 FEM 温度解析老行い，各施工目地に扔 ける打継目でのひび割れ発生の可能性を検討しひび割 机発生の可能性が高い場合には鉄筋により補強すること とした。

温度解析は, 図-7 に示す 3 力所の打継目に対し検討 を行った。例として，柱頭部箱析部とフィン部の打継目 に対して検討を行った着目点 1 の検討結果を示す。ひび 割机指数の解析結果が図-8である。コンクリート標準 示方書1 では，ひび割れを防止したい場合，ひび割れ指 数を 1.75 以上にすることと規定さ机ていることから， 本橋梁では，ひび割れ指数 1.8 以下の部分に対して検討 を行うこととした。また，ひび割机幅の制限値は，特に 撖しい腐食性環境を考慮して 0.15 mm 以下とした。こ の結果，着目点 1 では，D 13 鉄筋を D 19 鉄筋の間に追 加配置することで許容值を満足するということが得られ

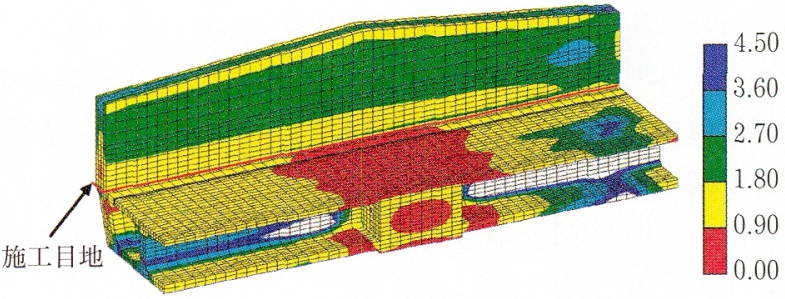

図-8 ひび割れ指数（着目点 1)

表-2 ひび割れ幅検討結果（着目点 1)

\begin{tabular}{|c|c|c|}
\hline 鉄筋配置 & D 19 ctc 125 & $\begin{array}{l}\text { D } 19 \operatorname{ctc} 125 \\
+ \text { D } 13 \operatorname{ctc} 125\end{array}$ \\
\hline かぶり $c(\mathrm{~mm})$ & 79.5 & 79.5 \\
\hline 鉄筋量 $A_{s}\left(\mathrm{~cm}^{2}\right)$ & 2.865 & 4. 132 \\
\hline $\begin{array}{l}A_{c t}\left(\mathrm{~cm}^{2}\right) \\
\left(A_{c t}=3.0 \cdot(t-d) \cdot \text { 鉄筋間隔 }\right)\end{array}$ & 298.1 & 298.1 \\
\hline$\rho\left(=A_{s} / A_{c t}\right)(\%)$ & 1.0 & 1.4 \\
\hline $\begin{array}{l}\text { ひび割机間隔 } s(\mathrm{~m}) \\
(s=\phi / 2.5 / \rho, \phi: \text { 鉄筋佳 })\end{array}$ & 0.79 & 0.55 \\
\hline 硬化温度上昇値 $T 1\left({ }^{\circ} \mathrm{C}\right)$ & 39.4 & 39.4 \\
\hline $\begin{array}{l}\text { 温度拘束ひずみ } \varepsilon \\
\left(\varepsilon=1.0 \cdot T 1 \cdot 10^{-5} / 2\right)\end{array}$ & $1.97 \mathrm{E}-04$ & $1.97 \mathrm{E}-04$ \\
\hline $\begin{array}{l}\text { ひび割れ幅 } W(\mathrm{~mm}) \\
(W=s \cdot \varepsilon)\end{array}$ & 0.16 & 0.11 \\
\hline 判定 $(W<0.15 \mathrm{~mm})$ & $N G$ & OK \\
\hline
\end{tabular}

Step1：仮設PCケーブル(1S28.6, 12本)緊張 Step3：下床版ケーブル(12S15.2)緊張
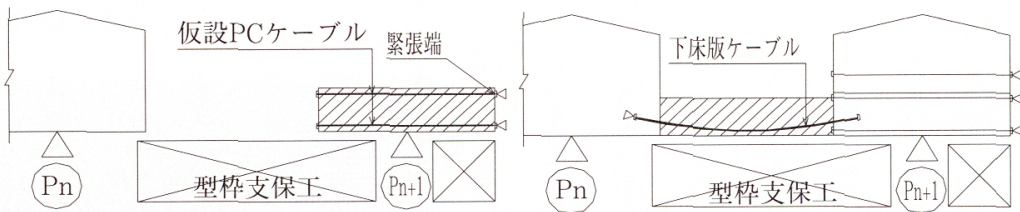

Step2：仮設PCケーブル (1S28.6, 4本) 緊張Ｓtep4：仮設PCケーブル(1S28.6, 4本)緊張力一部開放

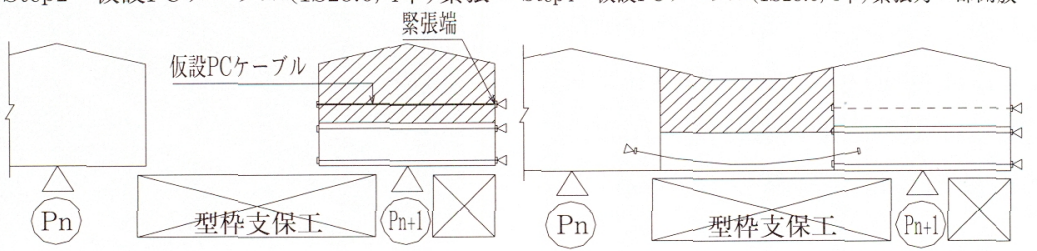

図-9 事前緊張施工手順 
た。これを表-2に示す。

\section{4 事前緊張によるひび割れ抑制}

1 つの施工区分を 4 分割でコンクリート打設を行うた め，最初に施工する橋脚上の箱桁部のコンクリート打設 から主ケーブルの緊張完了まで 60 日程度要する。この 上き，乾燥収縮による変形を型枠で拘束することでひび 割れが発生する可能性があるため，主ケーブルの一部お よび仮設ケーブルにプレストレスを与えることで，これ を抑制することとした。この手順を図-9に示す。

6. 施工

\section{1 試 験 施 工}

本橋梁では，フィンバックという特殊な形状であるこ とから，2 種類の試験施工を行っている。

（1）実物大模型によるコンクリート打設試験

本橋梁は，箱桁部とフィン部が一体になった構造になっ ており，鉄筋・ケーブル配置が複雑であるため，コンク リート打設の施工性が懸念された。さらに，フィン部の 部材厚が $1000 \mathrm{~mm}$ 上比較的大きく，水和熱による温度 ひび割れの発生等についても懸念された。

実物大模型を用いた打設試験では，実際に鉄筋・ケー ブルの配置を行い，その配置状況を確認し，打設時にコ ンクリートの充てん状況が確認できるように半透明型枠 を部分的に使用した。さらには，熱電対を配置し，内部 温度の测定屯行った。

（2） PCグラウト注入試験

フィン部に招ける $\mathrm{PC}$ 鋼材は, 最大高低差 $7.37 \mathrm{~m}$, 最大水平距離 $143.5 \mathrm{~m}$ ，最大傾斜角度 $24^{\circ} 12^{\prime} 36^{\prime \prime}$ で配置 されており，グラウトが確実に充てんできるか䀣念され た。そこで実施工に先立ち，真空ポンプ併用グラウトシ ステムを採用し，半透明シースを使用して実際のケーブ ル形状の試験体を製作し，グラウトの注入状況・充てん 状況の確認試験を行った。写真-1にグラウト試験体を 示す。

試験より，グラウト注入状況が確認でき，真空ポンプ を用いることで，特殊な形状のケーブルに招いても通常 に比心゙注入压力が小さく，有利に注入できること，シー スのリブや PC 鋼材の隙間にもグラウトが完全に注入で きることが確認できた。

\section{2 実 施 工}

本橋梁の施二に打ける特徵を以下に示す。

(1) 型枠工

本橋梁は，側面が $R=13.0 \mathrm{~m}$ の曲面になっており， また，フィン部の断面が大きいことから型枠の組立解体 時の効率化抢よび形状保持岡性を図るため, 鋼製フレー ムによる大型パネルとした。また，冬期羪生時の保温性 を考慮し，表面は合板を使用した。写真-2に型枠の組 立状況を示す。
(2) $\mathrm{PC}$ ケーブエ

主ケーブルは $12 \mathrm{~S} 15.2$, 横締めケーブルは $12 \mathrm{~S} 12.7$ を使用した。横締めケーブルは，デッドアンカーを用い た交互片引き方式としたが， $600 \mathrm{~mm}$ 間隔で配置され， 主ケーブル上複雑に交差しているため, 狭い空間での組 立作業となり困難な施工となった。主ケーブルの配置状 況を写真-3に，横締めケーブルの配置状況を写真-4に 示す。

（3）コンクリート工

使用するコンクリートの配合は，耐久性を考慮し，単

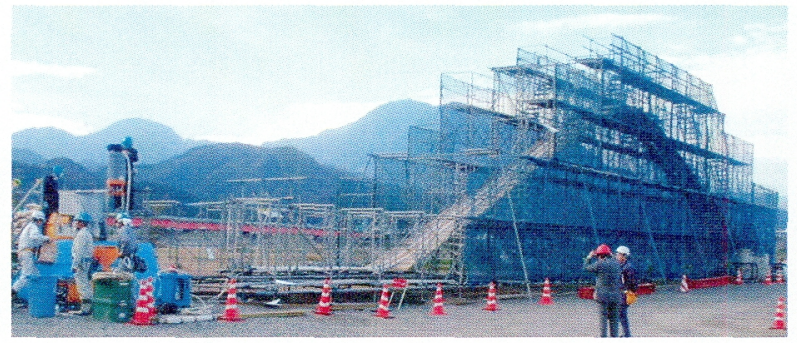

写真-1グラウト試験体

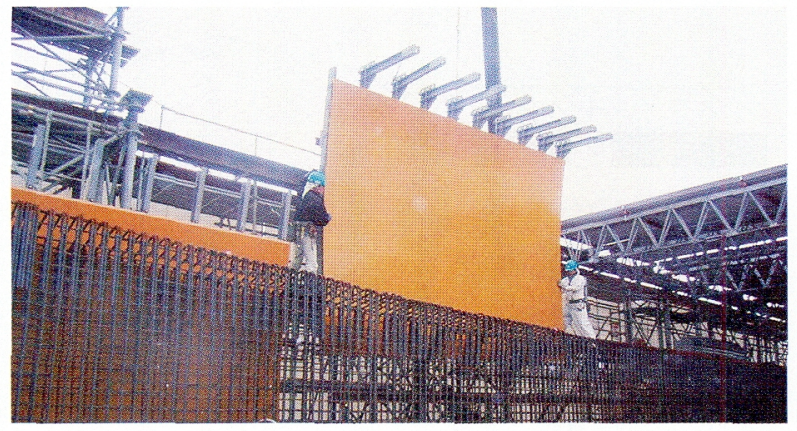

写真-2＼cjkstart型枠組立状況（箱桁部）

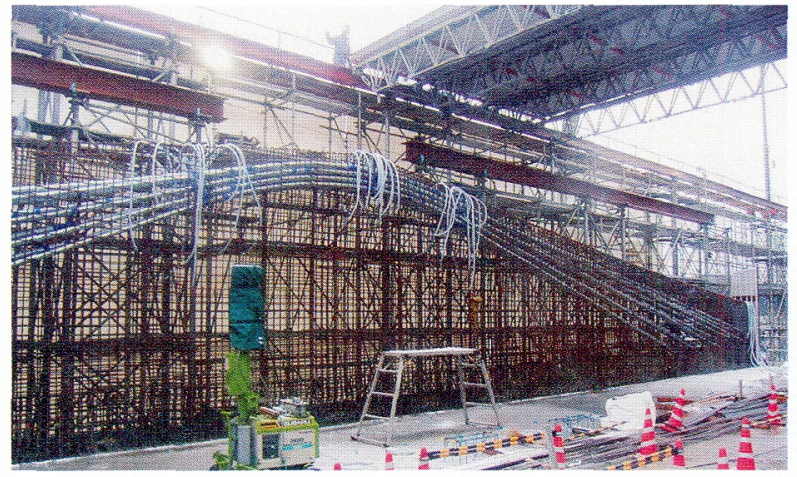

写真-3 主ケーブル配置状況

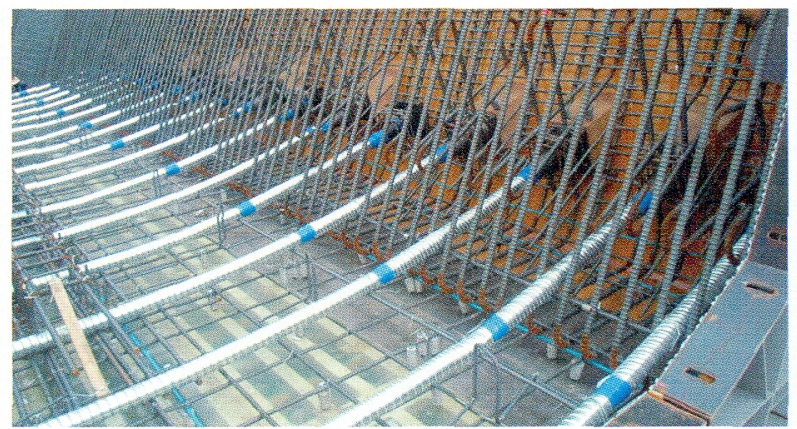

写真-4＼cjkstart横締めケーブル配置状況 
表-3 コンクリートの配合

\begin{tabular}{|c|c|c|c|c|c|c|c|c|}
\hline \multirow{2}{*}{$\begin{array}{c}\text { 設 } \\
\text { 計 } \\
\text { 基 } \\
\text { 準 } \\
\text { 強 } \\
\text { 度 } \\
\left(\mathrm{N} / \mathrm{mm}^{2}\right)\end{array}$} & \multirow{2}{*}{$\begin{array}{l}2 \\
5 \\
3 \\
70 \\
\\
(\mathrm{~cm})\end{array}$} & \multirow[b]{2}{*}{$\begin{array}{c}\text { 水 } \\
セ \\
x \\
y \\
⺊ \\
\text { 比 } \\
(\%)\end{array}$} & \multirow[b]{2}{*}{$\begin{array}{l}\text { 細 } \\
\text { 骨 } \\
\text { 材 } \\
\text { 率 } \\
\\
(\%)\end{array}$} & \multicolumn{5}{|c|}{ 単位重量 $\left(\mathrm{kg} / \mathrm{m}^{3}\right)$} \\
\hline & & & & $\begin{array}{l}セ \\
x \\
y \\
r\end{array}$ & 水 & $\begin{array}{l}\text { 細 } \\
\text { 骨 } \\
\text { 材 }\end{array}$ & $\begin{array}{l}\text { 粗 } \\
\text { 骨 } \\
\text { 材 }\end{array}$ & $\begin{array}{l}\text { 高 } \\
\mathrm{A} \\
\mathrm{E} \\
\mathrm{E} \\
\text { 機 } \\
\text { 能 } \\
\text { 型 } \\
\text { 水 } \\
\text { 剂 }\end{array}$ \\
\hline 40 & 12 & 42.0 & 50.0 & 393 & 165 & 878 & 878 & 4. 12 \\
\hline
\end{tabular}

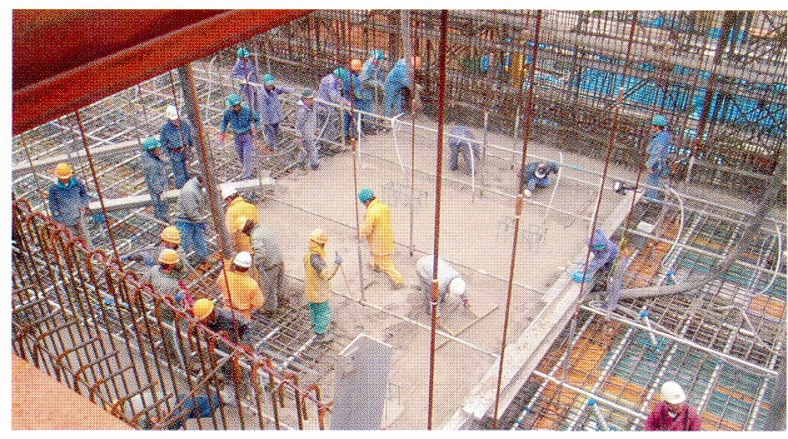

写真-5 コンクリート打設状況（箱桁部）

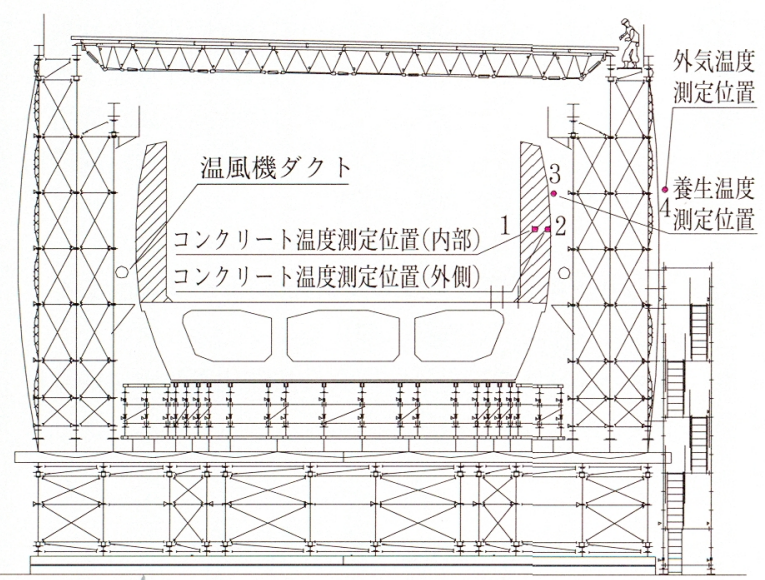

図-10 温度測定位置図

位水量を $175 \mathrm{~kg} / \mathrm{m}^{3}$ 以下，最大水セメント比を $43 \%$ 以

下，骨材の種類は無害骨材とすることと制限された。こ の条件を満たし，構造物の要求性能や耐久性を損称るよ うな初期欠宿を生じさせないこと，施工性等を考慮して 決定した配合を表-3に示す。ここでは，水セメント比 を小さくかつコンクリートの充てん性を確保するために 高機能型 $\mathrm{AE}$ 減水剂を用い，また，アルカリ骨材反応に 無害の骨材として石灰石骨材を用いた。

柱頭部の箱桁部では, 約 $640 \mathrm{~m}^{3}$ の全断面一括打設之な るため，上床版には吊り型枠を用い，4パーティーによ る打設を行った。この打設状沉を写真-5 亿示す。また， 側径間㧍よび中央径間のフィン部では，フィン部に浮き 型枠を用い，フィン部と上床版を一括で打設を行った。

施工では, 図-10に示した位置に熱電対を設置し, 養 生期間㧍よび型枠脱型時期を決定した。温度測定結果を 図-11 に示す。打設後はコンクリートファーネスを設置 して，養生温度を 5 日間 $10^{\circ} \mathrm{C}$ 以上に保っこととした。 また，型枠脱型時の温度差によるひび割れをを防止するた め,コンクリート外側温度と養生温度の差が $15^{\circ} \mathrm{C}$ 以内

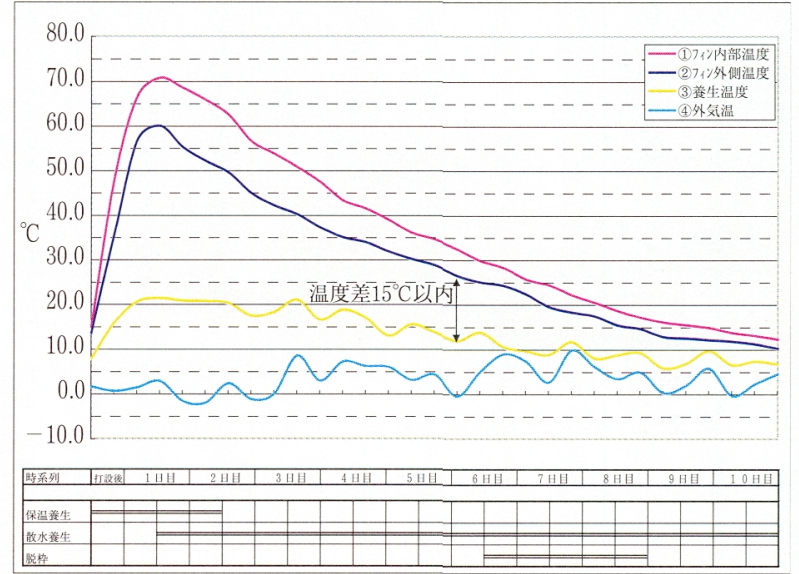

図-11 温度測定位置図

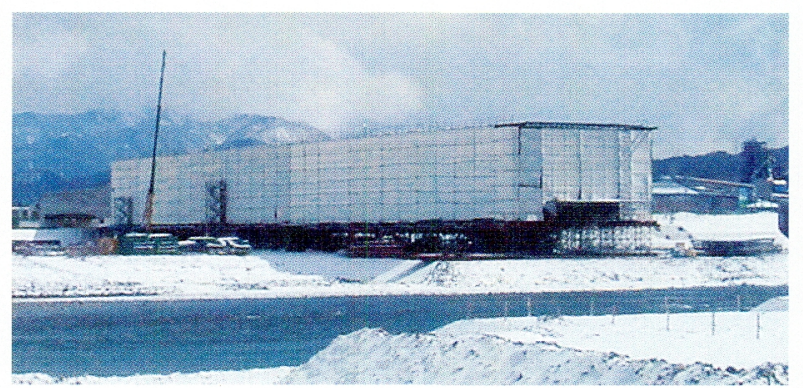

写真-6 養生仮囲い

表-4 防水工の種類と施工箇所

\begin{tabular}{c|c}
\hline 施丁筒所 & \multicolumn{1}{c}{ 防水工の種類 } \\
\hline \hline フィン内側側面, 橋面 & 浸透性コンクリート改質材 \\
\hline フィン外側側面, 底版 & 浸透性吸水防止材 \\
\hline 横締め跡埋め部 & コンクリート防蝕塗装材 \\
\hline
\end{tabular}

になったのを確認した後に脱型を行った。

(4) 養生仮囲い

本橋梁は，海岸線加ら約 $700 \mathrm{~m}$ に位置し，冬期は気 温が低く暴風雪の吹き荒れる日が多いため, 飛来塩分か らの防護, 適切な温度での養生, 良好な施工環境確保等 の日的で，写真-6 に示す仮囲いを設置し，屋根部を順 次移動させ施工圭行った。

(5)防水工

前述したように，本橋梁の施工位置は塩害環境下にあ り，さらには，河川上の構造物であることからメンテナ ンスも困難である。そこで，所定の鋼材かぶりを確保す るのみでは無く，耐久性向上策として橋桁全周に塩害対 策の防水塗装を行うこととした。表-4 に施丁筒所と使 用した防水工の種類を示す。

\section{7. おおりに}

本橋梁では，敵しい施工環境，および新幹線の橋梁形， 式として初のフィンバック橋という2つの大きな特幑を 有しているが，本稿で紹介した様々な検討・試験施工・ 工夫を重放ることにより，順調に施丁圭行っている。現 在は，2 期間の施工により第 5 施工分まで完了してお 


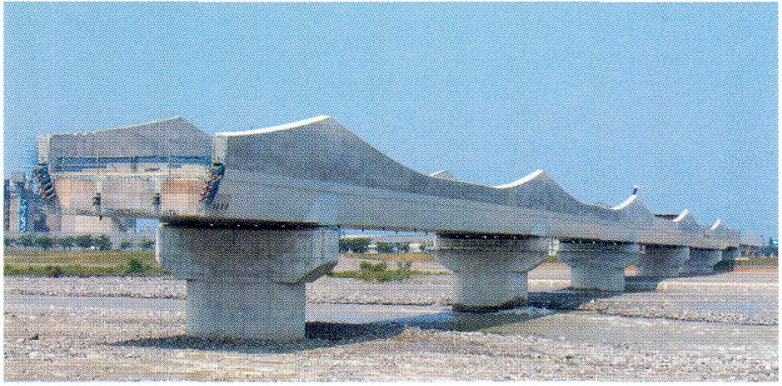

写真-7 第 2 施工期完了状況（平成 18 年 9 月現在）
完了する予定である。現在の状況を写真-7 に示す。本 報告が今後の長大コンクリート橋の発展の一助になれば 幸いである。

最後に，本橋梁の設計㧍よび施工に関し，ご指導，ご 協力を頂きました関係者各位に深く感謝し，ここに記し て謝意を表する次第です。

参 考 文 献

1）土木学会：コンクリート標準示方書 [2002 年版]施工編, p 43

り，本年 10 月からの施工で残りの 2 施工区分の施工を

$\leqslant$ 圈案内》

\section{「コンクリート構造物のリスクマネジメント研究委員会」報告書}

コンクリート構造物に関わるリスクについては，工事中は施丁者が，供用中は所有者や管理者がその責任を負うと一般的に考 えら机ています。しかし，構造物の完成後に生じる各種の不具合，早期劣化，事故，社会的影響等については，構造物の計画・ 設計・施工とも密接に関連することが多いので，それらの状況や程度によっては完成後といえども工事関係者の責任も追求され ます。一方，コンクリート構造物の設計・施工に性能規定の考え万が導入されつつあり，性能規定，あるいは性能発注が適用さ れると，設計や施工の自由度が広がる反面，設計者や施工者には構造物の性能を保証する責任が生じます。このことは，構造物 の品質・性能に対する製造者責任がより一層明確になることを意味しており，建設工事に携わる者によっては，リスクマネジメ ントは重要な課題となります。

この報告書は「コンクリート構造物のリスクマネジメント研究委員会（委員長：山本泰彦・筑波大学教授）」の活動成果をま とめたあのであり，まずリスクマネジメントの概念を示し，コンクリート構造物の計画から維持管理に至るまでのリスクマネジ メントについてケーススタディーを交えてわかりやすく概説しています。今後, この分野における研究を活性化させる基礎資料 となるとと屯に，建設実務にリスクマネジメントの概念走導入する際の参考になると考えられます。

まえがき

1.リスクマネジメントの概念

1.1 リスクマネジメントとは 1.2 リスクの視点とマネジメント $1.3 \quad$ リスク事象の範囲とマネジメント $1.4 \quad$ 情報の共 有化とマネジメント 1.5 リスクコミュニケーション 1.6 コンクリート構造物に扮けるリスクマネジメント

2. 計画から発注までのリスクマネジメント

2.1 公共事業に扔けるリスク分析と評価 2.2 民間事業におけるリスク分析と評価 2.3 調查・設計に沶けるリスク分析 と評価 2.4 入札・契約のリスク

3. 受注から竣工までのリスクマネジメント

3.1 コンクリート構造物の施工に抢けるリスク 3.2 コンクリート構造物の施工におけるリスク評価とマネジメント 3.3 施工に関わるリスクマネジメントの今後の課題

4. 供用・維持管理に打けるリスクマネジメント

4.1 概 要 4.2 刘象上する事象の整理 4.3 供用・維持管理分野における研究例・評価事例の紹介 4.4 供用・維持管 理に打けるリスクマネジメントの枠組み 4.5 ケーススタディーによる検討 4.6 供用・維持管理に関わるリスクマネジメン トの今後の課題

あとがき

付録リスクマネジメントに関連する用語（労働安全を含む）

A 4 判・231 ページ（2005年刊行）／定価 6300 円（税込），会員特価 5250 円（税込）／送料 390 円

-申込先：(社) 日本コンクリート工学協会「書籍販売」係

テ102-0083 東京都干代田区錮町 1-7 相互半蔵門ビル 12 階／電話（03）3263-1573

〈申込方法〉郵便振替（振替口座：00120-5-99133・加入者名：社団法人日本コンクリート工学協会）にて払い込み・甫申 し込み下さい。代金（書籍代・送料合計）受領次第沶送りします（振替手数料は中込者にてご負担願います）。 通信欄に書籍名・冊数・当協会会員の場合は会員番号を明記して下さい。

ご依頼人欄（お届け先）に郵便番号・住所・名称・担当者名・電話番号を必ず明記して下さい。 送料は 1 冊分の金額ですので，2冊以上お申し込みの場合は，お問い合わせ下さい。 